\title{
Oviductal regulation of fertilization and early embryonic development
}

\author{
W. C. Buhi ${ }^{1,2,3}$, I. M. Alvarez ${ }^{1}$ and A. J. Kouba ${ }^{3}$ \\ Departments of ${ }^{1}$ Obstetrics and Gynecology, ${ }^{2}$ Biochemistry and Molecular Biology and \\ ${ }^{3}$ Animal Science, University of Florida, Gainesville, FL 32610-0294, USA
}

\begin{abstract}
During the period of late follicular development and the first four days of the oestrous cycle, the oviduct occupies a central role in the establishment of pregnancy. Oviductal function is regarded as being either 'passive' or biologically active, providing an environment that sustains and enhances fertilization and early cleavage-stage embryonic development. Recent reports have focused on this microenvironment and shown that ovarian steroids induce marked morphological, physiological and biochemical changes. Alterations include changes in the biosynthetic activity and release of macromolecules by the oviductal epithelium which become part of the luminal microenvironment. Furthermore, both regional and temporal differences in activity and protein production occur through hormonal changes during the oestrous cycle and early pregnancy. Studies on identification, characterization and regulation of several proteins synthesized de novo have indicated oocyte-oviduct and embryo-oviduct interactions. However, the identification of oviduct-derived proteins, their regulation and their potential function in vivo needs to be examined. Studies in other species also suggest roles for growth factors in early embryonic development, but little information is available for the pig. We propose that ovarian hormones control changes in synthetic activity, synthesis of some oviduct-derived proteins and the presence of specific factors in the luminal microenvironment which sustain and enhance fertilization and early cleavage-stage embryonic development.
\end{abstract}

\section{Introduction}

The oviduct in many mammalian species, including the pig, is divided into three distinct regions: the infundibulum, ampulla and isthmus. Each segment has certain histological features that contribute to their particular physiological and biochemical functions. Although fertilization and early cleavage-stage embryonic development in the oviduct are not understood in detail, they are known to involve a highly complex series of cellular interactions within these regions. These interactions are clearly dependent upon the oviduct and its secretions for providing an essential in vivo physiological and biochemical microenvironment. The oviduct has been studied at times that are critical for the development of a pregnancy: preovulation, ovulation, fertilization, and early preimplantation development. These are significant for sperm transport, sperm binding and release, capacitation, capture and transport of oocytes, fertilization, and early cleavage-stage embryonic development and extend through the embryonic four-cell stage in the pig oviduct. The oviduct, in part, appears to be programmed for these events by ovarian steroids (Hunter, 1988).

There are two prevailing views regarding oviductal function (Gandolfi, 1995). First, the oviduct provides a 'passive' but optimal environment in terms of temperature, $\mathrm{pH}$, osmotic pressure, nutrients, oxygen tension and other factors. Second, this tissue is biologically active, providing a variety of protein secretory molecules which sustain and regulate or enhance events preceding and during fertilization, and in early embryonic development. Studies on the 'passive' physical environment (see, Hunter, 1988; Leese, 1988) have permitted development of techniques for 
improving in vitro fertilization and embryo development. However, recent studies on sperm-oviduct, oocyte-oviduct and embryo-oviduct interactions suggest regulation of activities through paracrine pathways by factors that may be embryotrophic. Oviductal biosynthetic activities and the identification and characterization of secretory and signalling molecules also suggest the presence of other embryotrophic factors. Here, current literature on the biologically active pig oviductal microenvironment is reviewed..

\section{Functional Histology}

The oviductal epithelial lining is composed of two major cell types, ciliated and nonciliated (secretory) cells. Scanning electron microscopy has shown marked cellular structural changes in these cells in pigs during oestrus and dioestrus (Wu et al., 1976; Abe and Oikawa, 1992). Dense ciliation was described in the ampulla and isthmus with well-rounded and bulbous secretory cells at oestrus. Ciliation decreased in the ampulla during the luteal phase without a concomitant change in the isthmus. Secretory granules are observed at all stages of the oestrous cycle but are more abundant at oestrus (Nayak and Zimmerman, 1971a). In pigs and other species, oviductal development is promoted by oestrogen while increased progesterone concentrations antagonize the effects of oestrogen (Nayak and Zimmerman, 1971b; Murray, 1992).

Our studies in sexually mature, cyclic Florida crossbred gilts have confirmed the effect of oestrogen. The effects have been further examined in relation to changes in cell height and cell type in the ampulla and isthmus. Ciliated and secretory cells reach maximal height by day 0 and this persists until day 6 of the oestrous cycle in both ampulla and isthmus. Cell height in both ampulla and isthmus decrease with increased concentrations of progesterone at dioestrus. An increase in cell height begins again at about day 18 in nonpregnant pigs in preparation for a new oestrous cycle. The percentage of ciliated cells $(80 \%)$ in the ampulla was greatest at oestrus and declined at dioestrus with a concomitant increase in nonciliated cells from $20 \%$ to $50 \%$. In contrast, the percentage of ciliated $(70-80 \%)$ and nonciliated $(20-30 \%)$ cells did not change throughout the oestrous cycle in the isthmus. These changes suggest a differential response of oviductal epithelium to endocrine regulation and this has been confirmed in studies with ovariectomized gilts treated with hormone replacement. Ovariectomized gilts that were treated with oestrogen showed an increased cell height in both ampulla and isthmus. Treatment of ovariectomized gilts with progesterone led to a lower cell height compared with the effect of oestrogen. In normal cyclic gilts, ovariectomy caused a loss of cilia in the ampulla, while oestrogen administration promoted ciliation. In contrast, progesterone treatment after ovariectomy did increase ciliation in the ampulla but not to the same extent as oestrogen. Progesterone also increased numbers of nonciliated cells to values that were previously seen with intact animals at dioestrus. However, regardless of steroid treatment, the number of ciliated or nonciliated cells in the isthmus did not change, in agreement with results in intact cyclic gilts. In nonciliated secretory cells of the ampulla, secretory granules were considerably more abundant at oestrus than on other days of the cycle (Fig. 1). Similarly, secretory granules were more abundant in epithelial cells in ovariectomized gilts treated with oestrogen compared with other steroid treatments. The appearance of these granules, which contained the porcine oviduct-specific protein (POSP) (Buhi et al., 1993), correlated with increased biosynthetic activity (see below). These changes, development of epithelial cell height, ciliation and the appearance of secretory granules, may reflect functional differences in intraluminal events of fertilization and early embryonic development.

\section{Oviductal Biosynthetic Activity}

Biochemical studies have shown the oviduct to be a dynamic tissue, synthesizing and releasing macromolecules into the lumen throughout the oestrous cycle and early pregnancy. These studies have focused on the use of radiolabelled amino acid precursors to examine the biosynthetic activity of the oviduct, a measure of its role in the contribution of macromolecules that may affect 

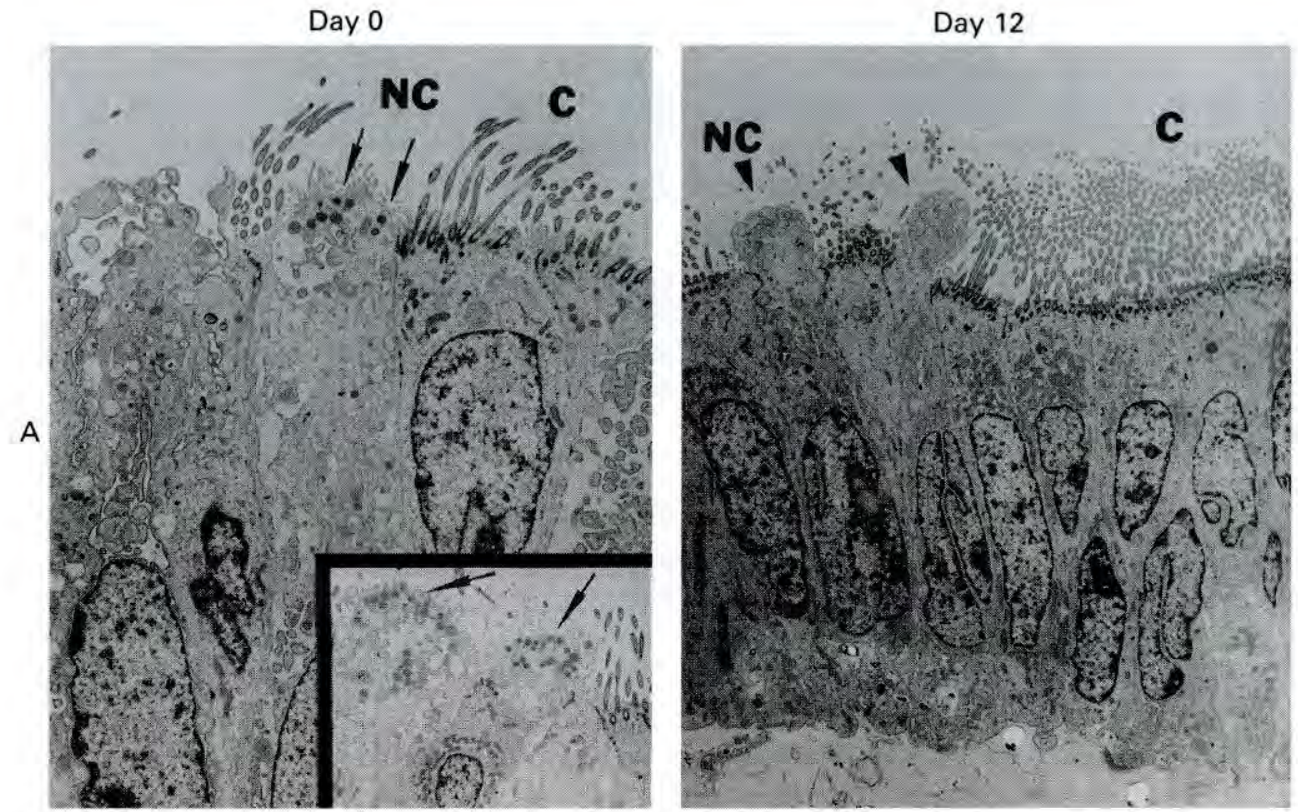

Fig. 1. Electronmicrographs of the oviductal ampullary (A) epithelium from pigs at day $0(\times 3500$; insert $\times 2500)$ and day $12(\times 2500)$ of pregnancy. Ciliated $(C)$ and nonciliated secretory (NC) cells are indicated. Secretory granules (arrows) are seen in the supranuclear region of nonciliated secretory cells in the ampulla from gilts at day 0 of pregnancy. Few, if any, secretory granules (arrowheads) are detected in the supranuclear region of nonciliated cells in gilts at day 12 of pregnancy.

fertilization and early cleavage-stage embryonic development. The biosynthetic activity of the oviduct has been measured in the pig during the oestrous cycle (Buhi et al., 1989), early pregnancy (Buhi et al., 1989), or following ovariectomy and steroid replacement (Buhi et al., 1992).

Evidence indicates that the biosynthetic activity of the oviduct is related to the hormonal status of the animal. Oestrogen-dominated animals have significantly greater synthetic activity, measured as incorporation of radiolabelled precursor into secreted nondialysable macromolecules, than progesterone-dominated animals. Greater incorporation was indicated at pro-oestrus, oestrus and metoestrus in pigs (Buhi et al., 1989) than on other days of the cycle. Differences in biosynthetic activity were not detected between cyclic and early pregnant gilts (Buhi et al., 1989), in contrast to observations in rabbits (Roy et al., 1972) in which differences were recognized. Uptake of amino acid precursor and incorporation into protein were reduced in pregnant rabbits, 14-70 h postcoitum, compared with that in nonpregnant rabbits. However, in pigs, the process of mating or the presence of gametes or embryos did not affect oviductal macromolecular protein synthesis. When gilts were unilaterally ovariectomized, biosynthetic differences were not detected in the oviduct ipsilateral or contralateral to the ovary containing the follicle or corpus luteum. These data suggest that circulating concentrations of ovarian hormones produced by one ovary were sufficient to control biosynthetic activities of both oviducts.

Changes in the biosynthetic activity of the whole oviduct and individual functional segments clearly indicated a temporal association of increased circulating concentrations of oestrogen with increased biosynthesis in the infundibulum, ampulla or whole oviduct (Buhi et al., 1989; W. Buhi, unpublished) (Fig. 2). In contrast, the biosynthetic activity did not change in the isthmus during the oestrous cycle or early pregnancy. The infundibulum and ampulla, regardless of hormonal status, had a biosynthetic capacity significantly greater (2-3 times) than that of the isthmus on all days of the oestrous cycle or early pregnancy, suggesting a differential response in biosynthetic activity of the different segments. 


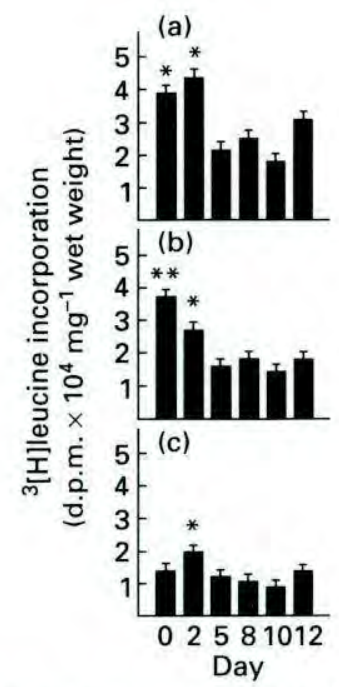

Fig. 2. Least squares means ( \pm SEM) of $\left[{ }^{3} \mathrm{H}\right]$ leucine incorporation (d.p.m. $\times 10^{4} \mathrm{mg}^{-1}$ wet tissue weight) into nondialysable macromolecules by oviductal tissue in explant culture from early pregnant Large White $\times$ Landrace gilts. Tissue collected from the (a) infundibulum, (b) ampulla and (c) isthmus. The incorporation of $\left[{ }^{3} \mathrm{H}\right]$ leucine is greater by the infundibulum on days 0 and 2 $\left({ }^{*} P<0.05\right)$, by the ampulla on day $0\left({ }^{* *} P>0.01\right)$ and day $2\left({ }^{*} P<0.05\right)$ and by the isthmus on day 2 $(P<0.05)$ than on other days of early pregnancy.

Evidence from these and other studies clearly suggest that steroids, and oestrogen in particular, upregulate the biosynthetic activity of the oviduct. The ovariectomized pig was used as a model to establish that the biosynthetic activity is steroid responsive (Buhi et al., 1992). The whole oviduct, infundibulum and ampulla responded with significantly greater biosynthetic activity after treatment with oestrogen compared with other treatments. The activity of whole oviduct and ampulla were greater than that of the isthmus, but the activity of the ampulla was always greater regardless of treatment.

\section{Proteins Synthesized De Novo By The Oviduct}

Information on a variety of proteins in oviductal fluids has been discussed in several reviews (Johnson and Foley, 1974; Hunter, 1988; and Leese, 1988). Many of these proteins, derived from serum and other fluids as a transudate, including enzymes and serum proteins such as albumin, transferrin and immunoglobulins, are present at concentrations lower than that found in serum. Total protein content, protein concentration and fluid volume in oviductal luminal fluid varies during the oestrous cycle and early pregnancy (Lippes et al., 1981; Sutton et al., 1984; Hunter, 1988). Increases in protein content and fluid appear to be temporally associated with increased concentrations of oestrogen. A variety of techniques using either oviductal organ explants or cultured epithelial cells have contributed to the identification and characterization of epithelialderived proteins in the oviductal environment. In the pig oviduct, gametes and fertilized eggs rely on oviductal secretions to provide macromolecules of a nutrient, protective, or stimulatory nature 
through the four- to eight-cell stage. As described below, some of these proteins are synthesized in a temporal and regional specific manner during the oestrous cycle and early pregnancy.

In pigs, the synthesis de novo and release of 14 major radiolabelled proteins (Buhi et al., 1990) have been identified and characterized by isoelectric point and relative molecular mass using twodimensional gel electrophoresis and fluorography (Fig. 3). Most of these 14 proteins as well as other minor proteins remain to be identified. The most abundant radiolabelled secretory product is a family of oviductal-specific proteins, porcine oviductal secretory proteins (POSP) 1-3 ( $M_{\mathrm{r}} 75000$ $85000, \mathrm{pI}<4 ; M_{\mathrm{r}} 100000, \mathrm{pI} 4-5.5 ; M_{\mathrm{r}} 100000, \mathrm{pI}>8$ ) the function of which is at present unknown. These proteins in the pig and similar oviduct-specific proteins identified in other species (cow, sheep, human, hamster, mouse and baboon) have been reviewed by Gandolfi (1995) and Buhi (1996). Several studies, including N-terminal amino acid sequence analysis (Buhi et al., 1993; Buhi et al., 1996a; W. Buhi and I. Alvarez, unpublished), carbohydrate analysis and lectin binding (W. Buhi and I. Alvarez, unpublished), western blot analysis (Buhi et al., 1993), in vitro translation and northern blot analysis (Buhi et al., 1996a) suggest that the three pig glycoproteins are related and most likely derived from a common precursor molecule. Expression of POSP is temporally associated with increased circulating concentrations of oestrogen during pro-oestrus, oestrus and early pregnancy (Buhi et al., 1989; Buhi et al., 1990). Studies in ovariectomized, steroid-treated gilts indicate that expression of the POSP family is oestrogen dependent and that this dependency is antagonized by progesterone (Buhi et al., 1992).

The complete cDNA sequence for POSP has been determined (Buhi et al., 1996a) and a full-length amino acid sequence deduced. This protein sequence exhibits a significant identity (65-78\%) and similarity (78-87\%) to oviductal-specific proteins from the cow (Sendai et al., 1994), sheep (DeSouza and Murray, 1995), human (Arias et al., 1994), mouse (Sendai et al., 1995), and hamster (Suzuki et al., 1995) indicating high conservation across species. In addition, sequence analyses revealed a significant similarity of POSP to the chitinase gene family. Products of this family, chitinases, are a well-studied group of enzymes the function of which is to cleave chitin, polymers of $\mathrm{N}$ acetylglucosamine. Hydrophobic cluster analysis (Woodcock et al., 1992), a secondary structure predictive method, also suggests a high similarity between POSP and bacterial chitinases. These analyses further indicate that the N-terminal domain of POSP corresponds to the catalytic domain of chitinases, whereas the C-terminal domain corresponds to a C-terminal extension which frequently represents a binding domain found in many cellulases and chitinases. These data suggest that the POSP C-terminal region, which also appears variable among the oviductal-specific proteins, may constitute a binding domain and function in both recognition and species specificity (Buhi et al., 1996a). Although POSP may structurally belong to this growing mammalian chitinase gene subfamily, the N-terminal domain lacks an essential glutamic acid residue, shown to be an absolute requirement for chitinase activity (Watanabe et al., 1993). Thus, while POSP lacks chitinase activity (Buhi et al., 1996a) it may potentially have other carbohydrate cleavage activity.

Steady state amounts of mRNA of POSP in the functional segments during the oestrous cycle correlate with synthesis of protein and biosynthetic activity. Furthermore, the amount of mRNA encoding POSP was significantly greater in the ampulla than in the infundibulum or isthmus regardless of day, and was greatest on day 0 regardless of location. Ovariectomy and hormone replacement confirmed that expression of mRNA encoding POSP was oestrogen dependent, as was synthesis of POSP protein (Buhi et al., 1996a). As with biosynthetic activity, synthesis of POSP protein was not different between cyclic and mated/early pregnant gilts confirming that mating, presence of gametes, or presence of embryos did not affect specific oviductal protein production. However, studies of synthesis of POSP protein showed both a regional distribution (ampulla $>$ infundibulum $>$ isthmus) and a temporal difference (days 1-3 > other days) (Buhi et al., 1990).

Although the function of this protein remains unknown, there are clear indications that POSP interacts with oocytes or embryos, potentially through a binding domain. Use of immunogold electromicroscopy showed that POSP was localized throughout the zona pellucida and perivitelline space, and associated with the vitelline membrane or plasma membrane of ovulated oocytes and oviductal early embryos (Fig. 4). POSP was similarly localized in unhatched uterine embryos (fourcell to blastocyst) and with the hatched embryo only to day 7 of pregnancy (Buhi et al., 1993). 
(a)

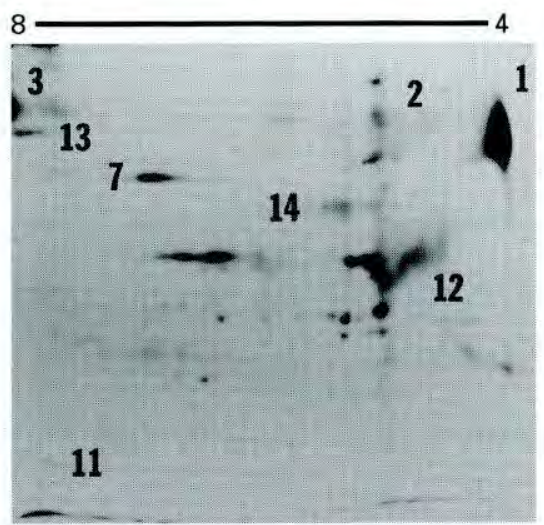

(b)

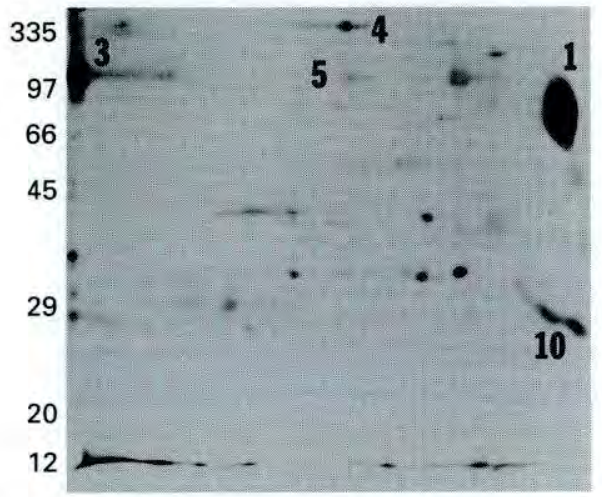

(c)

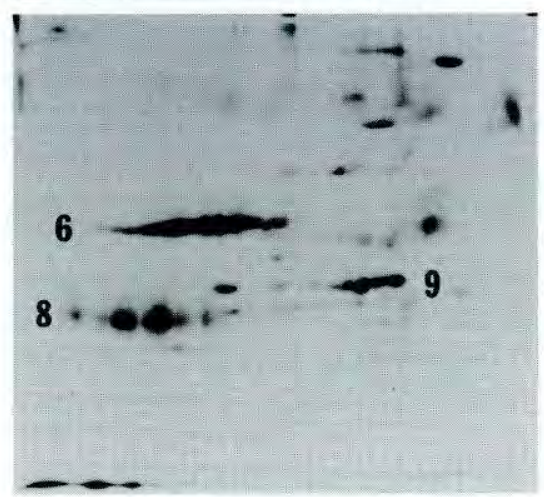

Fig. 3. Representative fluorographs after twodimensional polyacrylamide gel electrophoretic separation of proteins from explant culture medium conditioned by the infundibulum (a), ampulla (b) or isthmus (c). Tissue was collected from Large White $\times$ Landrace gilts on day 0 of pregnancy. Fourteen proteins, characterized by $M_{\mathrm{r}}$ and $\mathrm{pI}$, are indicated. Numbers 1-3, 6 and 8 represent porcine oviductal secretory protein (POSP), tissue inhibitor of metalloproteinase 1 (TIMP-1), and plasminogen activator inhibitor 1 (PAI-1), respectively. Molecular weight standards $\left(\times 10^{3}\right)$ are indicated and the $\mathrm{pH}$ gradient runs from left $(\mathrm{pH} 8)$ to right $(\mathrm{pH} 4)$. 

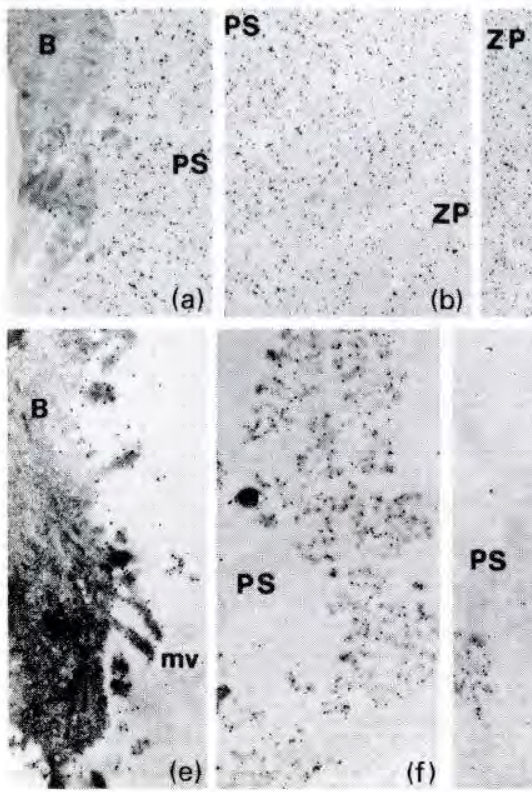

(b)
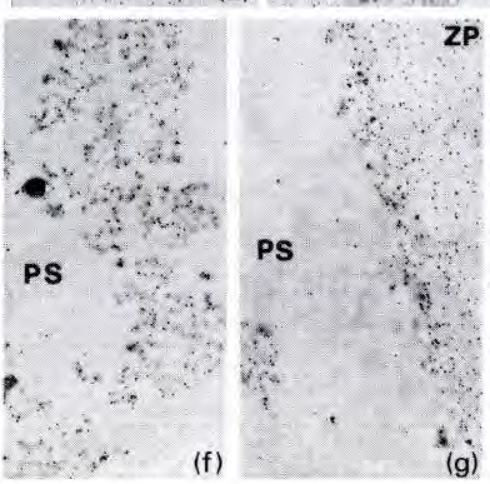

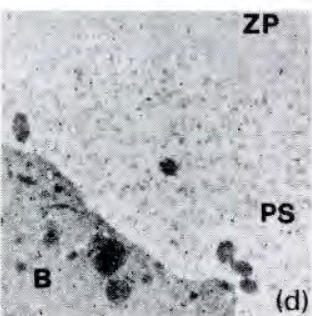

(d)

Fig. 4. Colloidal gold immunoelectron micrographs of pig oviductal (a-d) and uterine $(\mathrm{e}-\mathrm{h})$ four-cell embryos. Gold particles immunoreactive with porcine oviductal secretory protein (POSP) are associated with flocculent material (a, $\times 18000 ; \mathrm{b}, \times 18000)$ in the perivitelline space (PS) surrounding the blastomere (B) and in the zona pellucida $(\mathrm{ZP})(\mathrm{b} ; \mathrm{c}, \times 18000)$. Arrowheads (c) mark the location of sperm tails in the outer region of the ZP. Oviductal embryo treated with preimmune serum (d, $\times 18000)$. In the fourcell uterine embryos, immunoreactive gold particles were associated with the blastomere membrane and microvilli $(\mathrm{mv})(\mathrm{e}, \times 21000)$ and flocculent material in the PS $(f, \times 21000)$ and $Z P(g, \times 21000 ; h, \times 20000)$. Sperm heads (h, arrowheads) were located in the outer region of the ZP without apparent association of POSP. The clear sperm penetration pathway can be seen (h, arrow). (Reproduced from Buhi et al., 1993, with permission).

An appropriate question is whether the oocyte/embryo-associated POSP, and similar proteins, protect, signal or stimulate embryonic activity. Hill et al. (1996), using semi-purified ovine oviductspecific protein with in vitro fertilized and developed embryos, detected improved embryo cleavage rates when these were compared with control embryos. In our laboratory, semi-purified POSP and in vitro matured and fertilized bovine embryos were used and an increase in numbers of embryos proceeding to the four-cell and 16-cell stage was determined (A. Kouba and W. Buhi, unpublished). Wallenhaupt et al. (1996), using in vivo fertilized pig embryos and wheat germ agglutinin purified $97 \mathrm{kDa}$ oviductal-specific protein, showed an increase in the rate of incorporation of methionine into protein by four-cell embryos cultured in vitro from the one- or two-cell stage.

In contrast to the pronounced association of POSP with oocytes or embryos, data are conflicting concerning an interaction with spermatozoa. In pig (A. Kouba and W. Buhi, unpublished) and human (Reuter et al., 1994) studies, no association of spermatozoa and POSP or human oviductspecific protein, respectively, has been detected. However, Boatman and Magnoni (1995) and King and Killian (1994) indicated that the hamster and bovine oviductal-specific protein, respectively, bound to sperm membranes.

A recent study (Buhi et al., 1996b; Buhi et al., 1997) reported the identification of a second major protein synthesized de novo, tissue inhibitor of metalloproteinase (TIMP)-1, from the oviduct (Fig. 3, Protein 8). TIMPs are specific inhibitors of matrix metalloproteinases such as collagenases, stromelysins, and gelatinases (Werb and Alexander, 1993). The amount of mRNA encodingTIMP-1 
showed a significant effect of day and functional segment with greater amounts in the isthmus on day 2 than in other segments or days examined. Although TIMP-1 protein was synthesized de novo by all segments in cyclic and pregnant gilts, regional synthesis of TIMP-1 protein correlated with mRNA expression. In addition, TIMP-1 protein in oviductal flushings collected during the oestrous cycle, early pregnancy and after ovariectomy and steroid replacement was measured by radioimmunoassay. Significant differences in luminal fluid TIMP-1 concentrations were found by day, with day 0 being the greatest. Breed differences in TIMP-1 concentrations were also detected between standard Western and the prolific Chinese Meishan breeds. Immunostaining localized TIMP-1 in all segments of the oviduct during early pregnancy (day 0 to day 12). Furthermore, staining intensity correlated with TIMP-1 protein concentrations in oviduct flushing declining toward day 12 . Steroid control of expression of TIMP-1 mRNA and protein was examined. Steady state amounts of mRNA encoding TIMP-1 were significantly increased in ovariectomized gilts treated with oestrogen as were TIMP-1 protein synthesis and TIMP-1 protein concentration in oviductal fluid. In contrast, in intact pregnant gilts, the expression of TIMP-1 mRNA and TIMP-1 protein synthesis were greater with basal concentrations of oestrogen. Therefore, the increased concentration of TIMP-1 protein in oviductal fluid at day 0 was proposed to be due to some TIMP-1 protein being derived from serum transudate.

Although the role of TIMP-1 in the pig oviduct and with pig oocytes/embryos is unknown, this protein has the capability to function as a growth promoter or to participate in control of extracellular matrix remodelling. Satoh et al. (1994) suggested that TIMP-1 functions as an embryogenic stimulator of in vitro fertilized bovine embryos. Other studies have proposed regulatory roles in remodelling and as a growth promoter in the ovary (Smith et al., 1994). Addition of TIMP-1 to pig oocytes during in vitro maturation has been shown to improve cleavage rates after fertilization and during culture (Funahashi et al., 1997).

A third major oviductal protein (Fig. 3, protein 6) synthesized and released during the oestrous cycle and early pregnancy has been identified by $\mathrm{N}$-terminal amino acid microsequence analysis as pig plasminogen activator inhibitor (PAI)-1, a member of the serpin family of serine protease inhibitors (Kouba et al., 1997). Although PAI-1 is produced by all oviductal segments, it appears to be differentially expressed, with greater expression of protein by the isthmus than the ampulla or infundibulum. Comparison of PAI-1 synthesis by gilts in early pregnancy by two-dimensional polyacrylamide gel electrophoresis and fluorography confirmed significant differences by segment and between breeds (Kouba et al., 1997).

Both inhibitors, TIMP-1 and PAI-1, and potentially other unidentified protease inhibitors most likely serve to regulate the oviductal microenvironment and protect oocytes and embryos from proteolytic damage by enzymes in the lumen. Mechanistically, they act by preventing activation of enzymes or by binding to active proteinases to form a proteinase-inhibitor complex. These proteins may also be involved in maintaining a non-invasive environment, control extracellular matrix production and remodelling, development of blastomeres, or prevent premature hatching of embryos. As noted by Broermann et al. (1989), pig follicular oocytes and embryos exposed to the oviductal microenvironment are more resistant to in vitro proteolytic degradation than those not exposed to the oviduct or those recovered from the uterine environment.

Retinol-binding protein, which functions in the transport of retinol, can be found as a minor protein after two-dimensional gel electrophoretic analysis of oviduct-conditioned culture media (W. Buhi and I. Alvarez, unpublished). Harney et al. (1994) demonstrated by northern blot analysis that mRNA encoding RBP is present in the oviduct at day 0 .

In addition to these known proteins, at least 11 others are yet to be identified. Some of these 11 proteins appear to be differentially expressed, with synthesis and release being greater in the ampulla than in other segments. Others appear to be regulated by oestrogen or progesterone.

\section{Growth Factors and the Oviduct}

The precise role of growth factors or cytokines in oviductal function, fertilization and early embryonic development is unclear and remains intriguing. However, it is clear that gametes and 
Table 1. Growth factor, cytokine and receptor expression by the oviduct during the oestrous or menstrual cycle or early pregnancy

\begin{tabular}{lll}
\hline Factor & Gene expression & Protein expression \\
\hline IGF-I & $\mathrm{b}, \mathrm{o}, \mathrm{h}, \mathrm{m}, \mathrm{r}$ & $\mathrm{b}, \mathrm{h}, \mathrm{m}, \mathrm{p}$ \\
IGF-II & $\mathrm{b}, \mathrm{o}, \mathrm{h}, \mathrm{m}, \mathrm{r}, \mathrm{p}$ & $\mathrm{b}$ \\
IGF-IR & $\mathrm{o}$ & $\mathrm{p}, \mathrm{h}$ \\
IGF-BP $(1-6)$ & $\mathrm{h}, \mathrm{b}(2-5)$ & $\mathrm{h}, \mathrm{p}(1-4), \mathrm{b}(2-5)$ \\
EGF & $\mathrm{h}, \mathrm{m}, \mathrm{p}$ & $\mathrm{h}, \mathrm{m}, \mathrm{p}, \mathrm{bab}$ \\
TGF $\alpha$ & $\mathrm{b}, \mathrm{o}, \mathrm{h}, \mathrm{m}, \mathrm{p}$ & $\mathrm{h}, \mathrm{m}, \mathrm{p}, \mathrm{bab}$ \\
EGF-R & $\mathrm{h}, \mathrm{p}$ & $\mathrm{h}, \mathrm{p}, \mathrm{bab}$ \\
TGF $\beta 1$ & $\mathrm{o}, \mathrm{h}, \mathrm{m}$ & $\mathrm{h}, \mathrm{m}, \mathrm{p}$ \\
$\quad \beta 2$ & $\mathrm{~h}, \mathrm{~m}$ & $\mathrm{~h}, \mathrm{~m}, \mathrm{p}$ \\
$\quad \beta 3$ & $\mathrm{~h}, \mathrm{~m}$ & $\mathrm{~h}$ \\
TGF $\beta($ type I-III)R & $\mathrm{h}$ & $\mathrm{h}, \mathrm{p}$ (Type II) \\
HB-EGF & $\mathrm{h}, \mathrm{m}$ & $\mathrm{h}, \mathrm{m}$ \\
bFGF & $\mathrm{b}, \mathrm{o}$ & - \\
PDGF-AA, BB & $\mathrm{h}$ & $\mathrm{h}$ \\
PDGF $\alpha, \beta$ R & $\mathrm{h}$ & $\mathrm{h}$ \\
PDGF-B & $\mathrm{b}$ & $\mathrm{b}$ \\
Activin $\mathrm{B}_{\mathrm{A}}$ & $\mathrm{b}, \mathrm{m}\left(\mathrm{also} \beta_{\mathrm{B}}\right)$ & $\mathrm{b}, \mathrm{m}\left(\right.$ also $\beta_{\mathrm{B}}$ and $\left.\alpha\right)$ \\
TNF $\alpha$ & $\mathrm{m}$ & - \\
CSF-1 & $\mathrm{m}, \mathrm{p}$ & $\mathrm{m}, \mathrm{p}$ \\
GM-CSF & $\mathrm{h}$ & $\mathrm{h}$ \\
GM-CSF $\alpha \& \beta \mathrm{R}$ & $\mathrm{h}$ & $\mathrm{h}$ \\
\hline
\end{tabular}

$\mathrm{b}$, bovine; o, ovine; h, human; $\mathrm{m}$, mouse; $\mathrm{r}$, rat ; $\mathrm{p}$, porcine; bab, baboon.

preimplantation embryos of many species reside in an oviductal microenvironment in which they are exposed to growth factors and cytokines. Potentially, these factors operate in an autocrine and paracrine manner to regulate or modulate oviductal function (Gandolfi, 1995; Chegini, 1996) and/or embryonic and fetal growth and development (Schultz and Heyner, 1993). There is a growing body of evidence that a variety of growth factors markedly improve embryo development in culture (Gandolfi, 1995). Development is effected by increased protein and RNA synthetic rates, increased cell division, increased number of cells and increased blastocyst expansion and zona hatching rates (see Watson et al., 1994).

The source of growth factors in the oviduct of the pig and in other species, as with other proteins, is most likely from synthesis by the luminal secretory epithelium as well as from serum transudate. Investigations into the role of growth factors with early embryos stimulated identification of a number of growth factors within the oviductal environment (see Table 1). Expression of mRNA encoding epidermal growth factor (EGF) in the oviduct was measured as early as day 0 and day 1 of oestrus (W. Buhi, unpublished), while other studies have shown the presence of mRNA encoding EGF, EGF receptor (R), amphiregulin, and transforming growth factor (TGF) $\alpha$ on days 4 to 20 of the oestrous cycle in the pig (Kennedy et al., 1994). Swanchara et al. (1995) identified and quantitated EGF after extraction of oviductal tissue and collecting flushings in cyclic and pregnant gilts at $48 \mathrm{~h}$ after the onset of oestrus. Both EGF and TGF $\alpha$ protein were measured in oviductal flushings from mated and early pregnant (days $0,2,5,8,10$ and 12) gilts (W. Buhi and J. Diehl, unpublished) by radioimmunoassay. Although differences in concentration were not apparent for EGF, TGF $\alpha$ concentrations were significantly greater on day 0 than on other days. In ovariectomized gilts given steroid replacement, TGF $\alpha$ concentrations in oviductal fluids were significantly greater with oestrogen treatment than with any other hormonal treatment. Immunocytochemical studies have localized TGF $\alpha$, EGF and the EGF-R to epithelial cells of the infundibulum, ampulla and isthmus during the oestrous cycle, early pregnancy (Fig. 5a) and after ovariectomy and hormone replacement (Fig. 5b,c) in gilts. Similarly, Swanchara et al. (1995) localized EGF and EGF-R in the ampulla and 

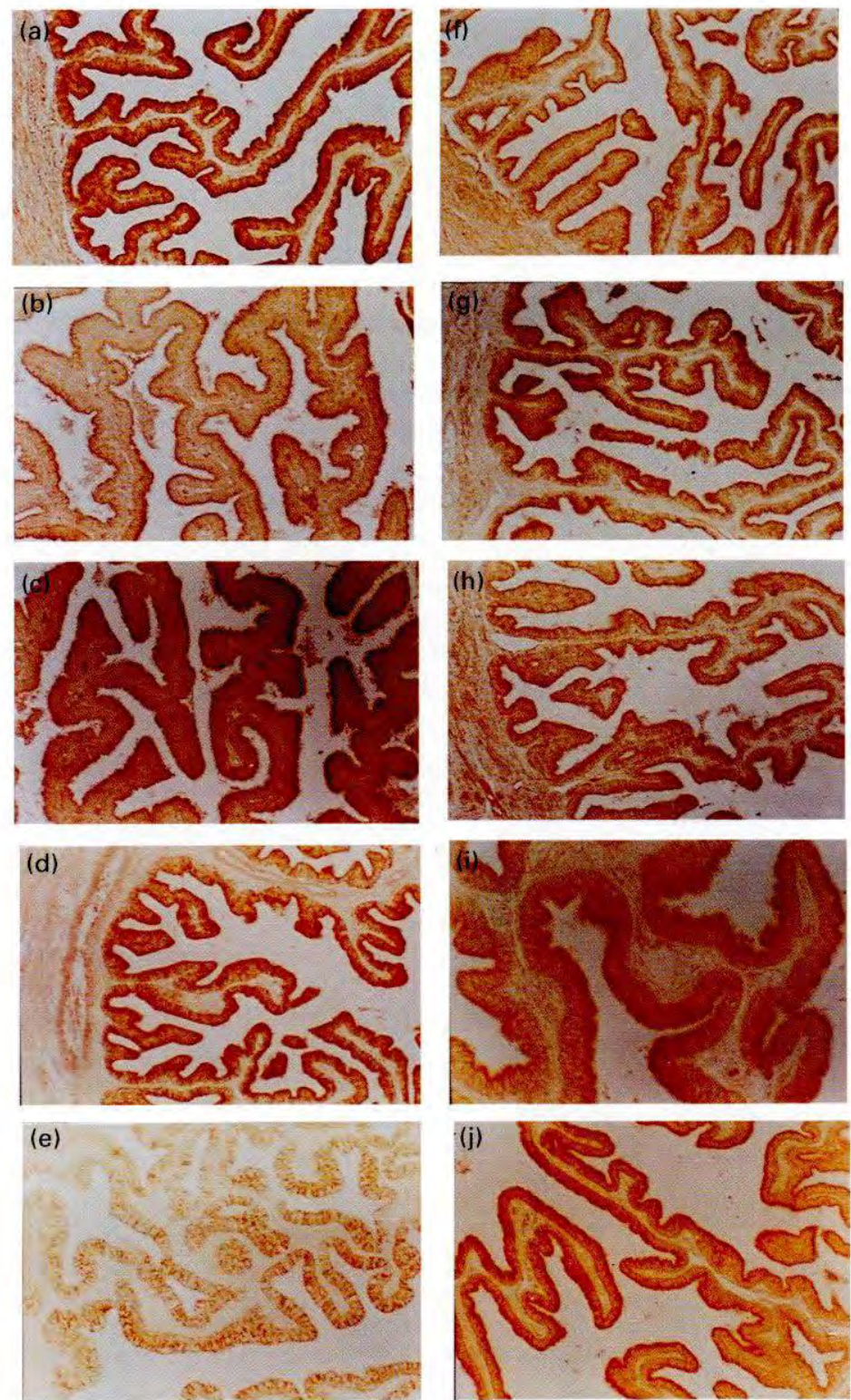

Fig. 5. Immunohistochemical localization of TGF $\alpha$ (a), EGF (b), EGF-R (c), IGF-I (d), IGFBP 1-3 (f-h), TGF $\beta 1$ (e), TGF 22 (i), and TGF $\beta$ Type II R (j) in pig oviductal tissue from a variety of reproductive states. Immunoreactive TGF $\alpha$ (a), IGF-I (d), and IGFBP 1-3 (f-h) were localized in the ampullary epithelium on day 0 of pregnancy (IGFBP 4 not shown). TGF $\beta 1$ (e), TGF $\beta 2$ (i) and TGF $\beta$ Type II R (j) were similarly localized in epithelium of ampullary tissue collected on day 1 of the oestrous cycle while EGF(b) and EGF-R(c) were localized in ampullary tissue from gilts ovariectomized and treated with $100 \mu \mathrm{g}$ oestradiol valerate for 11 consecutive days. 
isthmus at day 2 of the oestrous cycle or pregnancy. While the function of EGF and TGF $\alpha$ in the pig remains to be determined, promotion of blastocyst formation and stimulation of embryo development have been shown in co-culture studies with in vitro fertilized embryos (mouse and bovine) and oviductal cells, producing EGF and TGF $\alpha$, or without oviductal cells and added EGF (Morishige et al., 1993; Lonergan et al., 1996).

Insulin-like growth factors (IGF-I and IGF-II) regulate a variety of biological activities in many types of cell (Jones and Clemmons, 1994) and the actions of IGFs have been well characterized in pig uterine secretions (Simmen et al., 1993). Wiseman et al. (1992), using radioimmunoassay to measure IGF-I and IGF-II, demonstrated a higher content (concentration $\times$ fluid volume) of both factors in oviductal fluid collected at oestrus than at non-oestrous periods. IGF-I and IGF-II have also been measured in primary culture media collected after $48 \mathrm{~h}$ from oviductal epithelium at day 2 . Oviductal flushes from early pregnant gilts showed a significant increase in IGF-I concentration on days 0 and 2 compared with day 5 while a study with ovariectomized, steroid-treated gilts showed that IGF-I concentration in oviductal flushings was significantly greater with oestrogen treatment when compared with all other treatments (W. Buhi, unpublished). IGF-I has also been immunolocalized in the epithelium of the infundibulum, ampulla and isthmus during early pregnancy (Fig. 5d). IGF transport and function are also modulated by IGF -binding proteins (BP) (Jones and Clemmons, 1994). In the pig, IGFBP 1-4 were immunolocalized on epithelial cells of the infundibulum, ampulla and isthmus from day 0 to day 12 of pregnancy (Fig. $5 f-h$ ). Staining intensity of IGFBP-1 and -2 was greater than that of IGFBP-3 and -4 . These data indicate that IGFBPs are present and may modulate IGF activity in the oviduct. While a potential role for IGF-I has yet to be determined in the pig oviduct, IGF-I and insulin have each been shown to increase the percentage of bovine embryos developing to morulae by day 5 (Matsui et al., 1995).

Transforming growth factors (TGF) $\beta 1$, TGF $\beta 2$ and TGF $\beta$ type $\Pi$ receptor were localized by immunocytochemistry throughout the pig oviduct in all functional segments during the oestrous cycle and early pregnancy (Fig. 5e,i,j). Staining intensity of TGF $\beta 1$ and TGF $\beta$ type $\Pi$ receptor tended to decrease at dioestrus and increase at pro-oestrus, supporting hormonal control of these (Buhi $e t$ al., 1994). However, it is not known whether these factors are available to the developing embryo in oviductal fluid. Transcripts for TGF $\beta$ type II receptor were also detected by RT-PCR in oviductal RNA collected on days 0 and 1 of oestrus (W. Buhi, unpublished), while TGF $\beta 1$ transcripts have been found in cultured ovine oviductal epithelial cells (Watson et al., 1994). One role for TGFßs may be to modulate or regulate extracellular matrix proteins. A second possible role in the pig oviduct can be postulated from studies in cows which showed that TGF $\beta$, when combined with basic fibroblast growth factor, promoted the formation of blastocysts in vitro (Larson et al., 1992a).

Although not yet examined in pigs, expression of colony-stimulating factor (CSF-1), a haematopoietic growth factor, has been found in mouse oviducts during the first five days of pregnancy (Pampfer et al., 1991; Pollard, personal communication). In pigs, immunoreactive CSF-1 protein has been localized on luminal epithelium in early pregnant gilts (not shown). In addition, Tuo et al. (1995) detected CSF-1 transcripts in the pig oviduct in late dioestrus by northern blot analysis.

Transcripts and proteins for the above factors have also been determined by northern blot analysis, RT-PCR, in situ hybridization and immunoreactive studies in the bovine, human and mouse oviduct (Watson et al., 1992; Chegini, 1996; Dalton et al., 1994) (Table 1). Other growth factors found in the oviduct include platelet-derived growth factor (PDGF)- $\beta$ and basic fibroblast growth factor (Viuff et al., 1995), activin beta A (Gandolfi et al., 1995) and granulocyte-macrophage (GM)CSF and GM-CSF receptor (Chegini, 1996). However, it remains to be shown whether these factors are present in the pig oviduct, whether they are available to developing embryos and, if so, what their function may be. One role reported for PDGF was its promotion of bovine embryo development beyond the eight-cell stage (Larson et al., 1992b).

Whether there is a direct effect of growth factors and cytokines on pig oocytes or embryos from fertilization through the 4- to 8-cell stage is not clear. At this developmental stage, the presence of specific receptors on pig oocytes and embryos has not yet been determined. However, one study has reported expression of mRNA encoding EGF-R in pig embryos as early as day 7 of pregnancy 
(Vaughan et al., 1992). Similarly, transcripts for insulin and IGF-I receptors were detected in ovine embryos from the one-cell to blastocyst stage (Watson et al., 1994), while transcripts for IGF-I, IGF-II, IGFBP2-4 and PDGF- $\alpha$ receptor were found at all stages of early bovine development from mature oocyte to the blastocyst (Watson et al., 1992; Winger et al., 1997). Thus, these data suggest the potential for autocrine and paracrine growth factor interactions between the oviduct and early cleavage-stage embryos.

\section{Co-culture Studies, Spermatozoa and Zona Pellucida}

Although embryos will develop in vitro, they will not develop to the same potential when cultured in chemically defined media, or with uterine or other cell types as in vivo (Murray et al., 1995). Coculture experiments with embryos in vitro or embryo transfer studies in several species have established the importance of oviductal secretions, oviductal-specific proteins and oviductal epithelial cells for enhancing fertilization and embryonic development (Petters and Wells, 1993). Specifically, pig oviductal secretions (Archibong et al., 1989), oviductal epithelial cells (White et al., 1989), and organ (oviduct) culture (Krisher et al., 1989) were shown to be beneficial for embryo development.

Brown and Cheng (1986) and Hedrick et al. (1987) have shown that oviductal glycoproteins were bound to the zona pellucida in pigs after ovulation and fertilization, and during early embryonic development. Recent studies have shown that POSP associates with the zona pellucida (Buhi et al., 1993). Studies by Broermann et al (1989) indicated that pig follicular oocytes or embryos exposed to the oviduct microenvironment were more resistant to proteolysis than oocytes without oviductal exposure or embryos collected from the uterine environment, suggesting the uptake of protective agents from the oviduct. The presence of two identified major protease inhibitors in oviductal fluid and other, as yet unidentified, proteinase inhibitor(s) may account for this increased resistance to proteases by oocytes and embryos (Buhi et al., 1997; Kouba et al., 1997).

Polyspermy is a major complication during in vitro fertilization of pig oocytes. Nagai and Moor (1990) reduced the incidence of polyspermy with pig oocytes by incubation of oocytes and spermatozoa with oviductal secretory molecules. Co-culturing spermatozoa with oviductal cells for only $30 \mathrm{~min}$ was shown to reduce polyspermy (Dubuc and Sirard, 1995). With natural breeding, sperm interact with oviductal cells, spending up to $36 \mathrm{~h}$ at the tubo-uterine junction associated with isthmic epithelium (Hunter, 1988). Incubation of boar spermatozoa with oviductal explants show an intimate association of spermatozoa with epithelium which is independent of oviductal region or day of oestrous cycle (Suarez et al., 1991). A second study observed spermatozoa binding to the isthmus more readily than to the ampulla (Raychoudhury and Suarez, 1991). This binding may be through specific receptors or glycoprotein interactions. Raychoudhury et al. (1993) used a variety of lectins to show distribution of glycosylated molecules on the oviductal mucosa at oestrus and dioestrus and after ovariectomy and steroid treatment. The patterns of lectin binding varied with hormonal state and region. In other experiments, De Mott et al. (1995) indicated that sialylated oligosaccharides may mediate binding of hamster spermatozoa to oviductal epithelium and suggested that release of spermatozoa may be accomplished by modification of binding components. Furthermore, binding of spermatozoa by oviductal cells was also shown to increase motility and penetration when compared with spermatozoa that had not bound (Dubuc and Sirard, 1995). Two additional studies suggested a sperm-oviductal protein interaction. Boatman and Magnoni (1995) showed that the hamster oviduct-specific glycoprotein enhanced binding of spermatozoa to the zona pellucida and the zona pellucida-induced acrosome reaction. In the second study, O'Day-Bowman et al. (1996) showed that incubation of human oviduct-specific glycoprotein with human spermatozoa and hemizona increased binding of spermatozoa to the hemizona. These data clearly indicate a role for the oviduct or its secretions in enhancing sperm-oocyte interactions. 


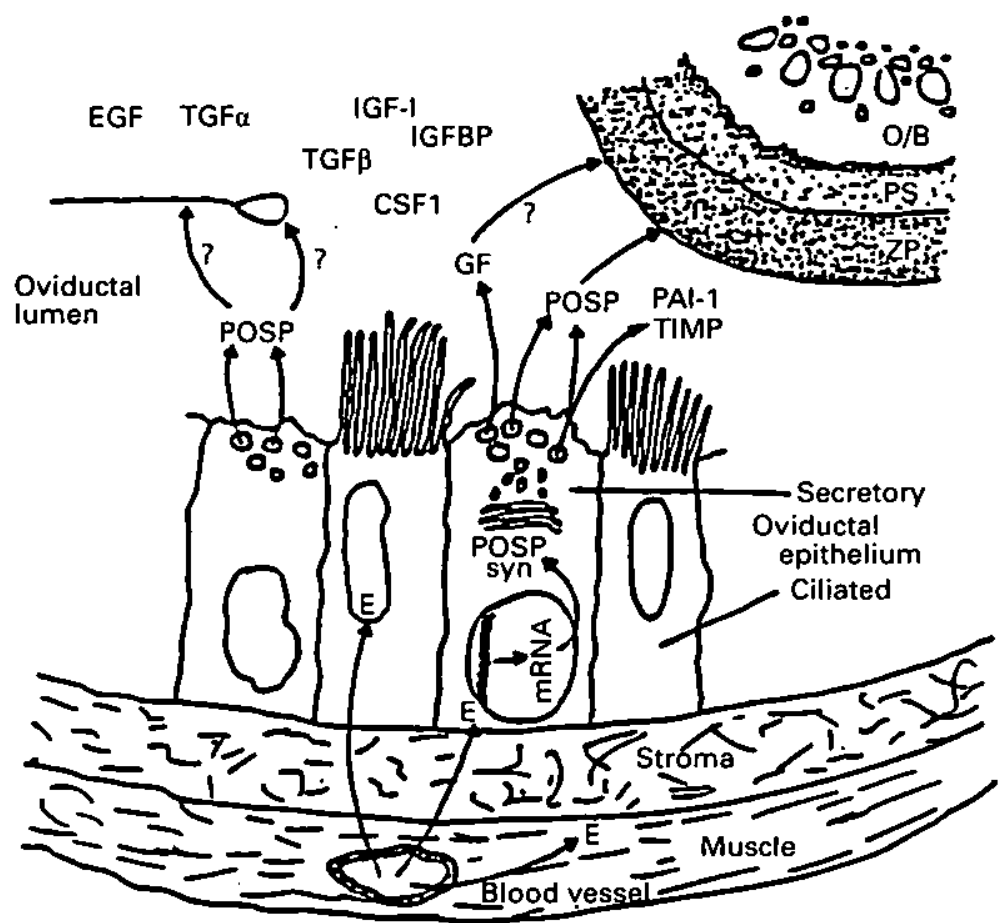

Fig. 6. Ciliated and secretory epithelium achieve maximum development, biosynthetic capacity and secretory activity with oestrogen during the periods of folliculogenesis, ovulation, and early cleavage-stage embryonic development. The secretory products that are contributed to the oviductal luminal microenvironment potentially operate in an autocrine and/or paracrine manner to regulate oviductal and embryonic growth and development.

\section{Conclusions}

Studies of the pig oviduct have provided information ' on its biological (synthetic) activity and a variety of protein secretory molecules contributed to and found within the oviductal microenvironment during periods of ovulation, fertilization and early cleavage-stage embryonic development (Fig. 6). POSP and the equivalent oviduct-specific proteins found in other species with a high conservation of structure suggest important roles in oviductal events. Important questions remain concerning identification of oviductal-derived proteins, purification of individual proteins, their regulation and their biological function. For example, how do those molecules, contributed in a temporal and regional specific manner to oviductal luminal fluid, participate in events of fertilization and early cleavage-stage embryonic development? Although growth factors are multifunctional regulators of cellular activities, a direct demonstration of their involvement with early cleavage-stage (one- to eight-cell stage) embryonic development is lacking in pigs. However, in vitro studies in several other species suggest the potential importance of these factors on embryonic development during this time. Complementary studies, which use individually purified or combined oviductal-derived proteins and growth factors in an in vitro fertilization and culture system, as well as methods that inhibit expression of these agents in vivo, will be necessary to establish function and understand their mechanism of action.

This paper was supported by grants from the USDA (92-37203-7996 to W. C. Buhi and F. A. Simmen and 9537203-2308 to W. C. Buhi). The authors thank B. Cleaver for statistical analysis and G. Erdos and R. Davis of the Electronmicroscopy Core Laboratory. 


\section{References}

Abe $\mathrm{H}$ and Oikawa T (1992) Examination by scanning electron microscopy of oviductal epithelium of the prolific Chinese Meishan pig at follicular and luteal phases Anatomical Record 233 399-408

Archibong AE, Petters RM and Johnson BH (1989) Development of porcine embryos from one- and two-cell stages to blastocysts in culture medium supplemented with porcine oviductal fluid Biology of Reproduction 41 1076-1083

Arias EB, Verhage HG and Jaffee RC (1994) Complementary deoxyribonucleic acid cloning and molecular characterization of an estrogen-dependent human oviductal glycoprotein Biology of Reproduction 51 685-694

Boatman DE and Magnoni GE (1995) Identification of a sperm penetration factor in the oviduct of the golden hamster Biology of Reproduction 52 199-207

Broermann DM, Xie S, Nephew KP and Pope WF (1989) Effects of the oviduct and wheat germ agglutinin on enzymatic digestion of porcine zona pellucidae Joumal of Animal Science 67 1324-1329

Brown CR and Cheng WKT (1986) Changes in composition of the porcine zona pellucida during development of the oocyte to the 2- to 4-cell embryo Journal of Embryology and Experimental Morphology 77 411-417

Buhi WC (1996) Cyclic changes in the oviduct during fertilization and early cleavage-stage embryonic development Archives of Animal Breeding 39 15-25

Buhi WC, Vallet JL and Bazer FW (1989) De novo synthesis and release of polypeptides from cyclic and early pregnant porcine oviductal tissue in explant culture The jourmal of Experimental Zoology 252 79-88

Buhi WC, Alvarez IM, Sudhipong V and Dones-Smith MM (1990) Identification and characterization of de novo-synthesized porcine oviductal secretory proteins Biology of Reproduction 43 929-938

Buhi WC, Ashworth CJ, Bazer FW and Alvarez IM (1992) In vitro synthesis of oviductal secretory proteins by estrogentreated ovariectomized gilts The Journal of Experimental Zoology 262 426-435

Buhi WC, O'Brien B, Alvarez IM, Endos G and Dubois D (1993) Immunogold localization of porcine oviductal secretory proteins within the zona pellucida, perivitelline space, and plasma membrane of oviductal and uterine oocytes and early embryos Biology of Reproduction 48 1274-1283

Buhi WC, Chegini N, Rong H and Alvarez 1 (1994) Immunolocalization of transforming growth factor (TGF- $\beta$ ) TGF- $\beta 1$, TGF- $\beta 2$, and TGF- $\beta$ type II receptor protein in the porcine oviduct Society for Gynecological Investigation Chicago

Buhi WC, Alvarez IM, Choi I, Cleaver BD and Simmen FA (1996a) Molecular cloning and characterization of an estrogendependent porcine oviductal secretory glycoprotein Biology of Reproduction 55 1305-1314

Buhi WC, Alvarez IM, Pickard AR, Ashworth CJ, McIntush EW and Smith MF (1996b) Tissue inhibitor of metalloproteinase (TIMP)-1 in the porcine oviduct during early pregnancy (EP) and the estrous cycle (EC) Biology of Reproduction 54 (Supplement 1) 103

Buhi WC, Alvarez IM, Pickard AR, McIntush EW, Kouba AJ, Ashworth CJ and Smith MF (1997) Expression of tissue inhibitor of metalloproteinase (TIMP)-1 protein and mRNA by the oviduct of cyclic, early pregnant, and ovariectomized steroid-treated gilts Biology of Reproduction 57 7-15
Chegini N (1996) Oviductal-derived growth factors and cytokines: implication in preimplantation Seminars in Reproductive Endocrinology 14 219-229

Dalton T, Kover K, Dey SK and Andrews GK (1994) Expression of growth factor, interleukin-1, and lactoferrin genes and the distribution of inflammatory leukocytes in the preimplantation mouse oviduct Biology of Reproduction 51 $597-606$

DeMott RP, Lefebvre R and Suarez SS (1995) Carbohydrates mediate the adherence of hamster sperm to oviductal epithelium Biology of Reproduction 52 1395-1403

DeSouza MM and Murray MK (1995) An estrogen-dependent secretory protein which shares identity with chitinases, is expressed in a temporally and regionally specific manner in the sheep oviduct at the time of fertilization and embryo development Endocrinology 136 2485-2496

Dubuc A and Sirard MA (1995) Effect of coculturing spermatozoa with oviductal cells on the incidence of polyspermy in the pig in vitro fertilization Molecular Reproduction and Development 41 360-367

Funahashi H, McIntuch EW, Smith MF and Day BN (1997) Effect of tissue inhibitor of metalloproteinases (TIMP-1) on early development of swine oocytes matured and fertilized in vitro. Theriogenology 47277

Gandolfi F (1995) Functions of proteins secreted by oviductal cells Microscopy Research and Technique 32 1-12

Gandolfi F, Modina S, Brevini TA, Passoni L. Artini P, Petraglia F and Lauria A (1995) Activin beta A subunit is expressed in bovine oviduct Molecular Reproduction and Development 40 286-291

Hamey JP, Smith LC, Simmen RCM, Fliss AE and Bazer FW (1994) Retinol-binding protein: immunolocalization of protein and abundance of messenger ribonucleic acid in conceptus and maternal tissues during pregnancy in pigs Biology of Reproduction 50 1126-1135

Hedrick JL, Wardrip NJ and Berger T (1987) Differences in the macromolecular composition of the zona pellucida isolated from pig oocytes, eggs and zygotes The joumal of Experimental Zoology 241 257-262

Hill JL, Walker SK, Brown GH and Nancarrow CD (1996) The effects of an estrus-asseciated oviductal glycoprotein on the in vitro fertilization and development of ovine oocytes matured in vitro. Theriogenology 46 1379-1388

Hunter RHF (1988) The Fallopian Tubes: Their Role in Fertility And infertility Springer-Verlag, Berlin

Johnson $A$ and Foley (1974) The Oviduct and its Function Academic Press, New York

Jones J and Clemmons D (1994) Insulin-like growth factors and their binding proteins: biological actions Endocrine Reviews 16 3-34

Kennedy TG, Brown KD and Vaughan TJ (1994) Expression of genes for the epidermal growth factor receptor and its ligands in porcine oviduct and endometrium Biology of Reproduction 50 751-756

King RS and Killian GJ (1994) Purification of bovine estrusassociated protein and localization of binding on sperm Biology of Reproduction 51 34-42

Kouba AJ, Alvarez IM and Buhi W (1997) Purification and characterization of a $45 \mathrm{kDa}$ protein synthesized de now by oviductal tissue from early pregnant and ovariectomized (OVX) steroid-treated gilts Biology of Reproduction 56 (Supplement 1) 187 
Krisher RL, Petters RM, Johnson BH, Bavister BD and Archibong AE (1989) Development of porcine embryos from one-cell stage to blastocyst in mouse oviducts maintained in organ culture The Journal of Experimental Zoology 249 235-239

Larson RC, Ignotz GG and Currie WB (1992a) Transforming growth factor $\beta$ and basic fibroblast growth factor synergistically promote early bovine embryo development during the fourth cell cycle Molecular Reproduction and Development 33 432-435

Larson RC, Ignotz GG and Currie WB (1992b) Platelet derived growth factor (PDGF) stimulates development of bovine embryos during the fourth cell cycle Development 115 $821-826$

Leese HJ (1988) The formation and function of oviduct fluid Journal of Reproduction and Fertility 82 843-856

Lippes J, Krasner J, Alfonso LA, Dacalos ED and Lucero R (1981) Human oviductal fluid proteins Fertility and Sterility 36 $623-629$

Lonergan P, Carolan C, Van Langendonckt A, Donnay I, Khatir $\mathbf{H}$ and Mermillod P (1996) Role of epidermal growth factor in bovine oocyte maturation and preimplantation embryo development in vitro. Biology of Reproduction 54 1420-1429

Matsui M, Takahashi Y, Hishinuma $\mathbf{M}$ and Kanagawa H (1995) Insulin and insulin-like growth factor-I (IGF-I) stimulate the development of bovine embryos fertilized in vitro. Joumal of Veterinary Medical Science 57 1109-1111

Morishige $K$, Kurachi $H$, Amemiya $K$, Adachi $H$, Adachi $K$, Sakoyama Y, Miyake A and Tanizawa O (1993) Menstrual stage-specific expression of epidermal growth factor and transforming growth factor-alpha in human oviduct epithelium and their role in early embryogenesis Endocrinology 133 199-207

Mumay MK (1992) Biosynthesis and immunocytochemical localisation of an estrogen-dependent glycoprotein and associated morphological alterations in the sheep ampulla oviduct Biology of Reproduction 47 889-902

Murray MK, DeSouza MM and Messinger SM (1995) Oviduct during early pregnancy: hormonal regulation and interactions with the fertilized ovum Microscopy Research and Technigues 31 497-506

Nagai T and Moor RM (1990) Effect of oviductal cells on the incidence of polyspermy in pig eggs fertilized in vitro. Molecular Reproduction and Development 26 377-382

Nayak RK and Zimmerman DR (1971a) Ultrastructural changes in porcine oviduct epithelium during the estrous cycle Journal of Animal Science 33262

Nayak RK and Zimmerman DR (1971b) Effect of estrogen and progesterone on the ultrastructure of porcine oviduct epithelium Journal of Animal Science 331161

O'Day-Bowman MB, Mavrogianis PA, Renter LM, Johnson DE, Fazleabas AT and Verhage HG (1996) Association of oviductspecific glycoproteins with human and baboon (Papio anubis) ovarian oocytes and enhancement of human sperm binding to human hemizona following in vitro incubation Biology of Reproduction 54 60-69

Pampfer S, Arceci RJ and Pollard JW (1991) Role of colony stimulating factor-1 (CSF-1) and other lymphohematopoietic growth factors in mouse preimplantation development BioEssays 13 535-540

Petters RM and Wells KD (1993) Culture of pig embryos Journal of Reproduction and Fertility Supplement 48 61-73

Raychoudhury SS and Suarez SS (1991) Porcine sperm binding to oviductal explants in culture Theriogenology 36 1059-1069
Raychoudhury SS, Suarez SS and Buhi WC (1993) Distribution of lectin binding sites in the oviducts of cycling and hormone-treated pigs The Journal of Experimental Zoology $265659-668$

Reuter LM, O'Day-Bowman MB, Mavrogianis PA, Fazleabas AT and Verhage HG (1994) In vitro incubation of golden (Syrian) hamster ovarian oocytes and human sperm with a human oviduct specific glycoprotein Molecular Reproduction and Development 38 160-169

Roy SR, Jr, Gupta DN, Roy SK, Karkun JN and Kar AB (1972) Studies in physiology and biochemistry of the fallopian tube. In vitro uptake of DL-valine-1-14 $\mathrm{C}$ by different parts of the rabbit fallopian tube during early pregnancy Endokrinologie 59 221-226

Satoh T, Kobayashi K, Yamashita S, Kikuchi M, Sendai $Y$ and Hoshi H (1994) Tissue inhibitor of metalloproteinases (TTMP-1) produced by granulosa and oviduct cells enhances in vitro development of bovine embryos Biology of Reproduction 50 835-844

Schultz GA and Heyner S (1993) Growth factors in preimplantation mammalian embryos Oxford Reviews of Reproductive Biology 15 43-81

Sendai Y, Abe H, Kikuchi M, Satoh T and Hoshi H (1994) Purification and molecular cloning of bovine oviductspecific glycoprotein Biology of Reproduction 50 927-934

Sendai Y, Komiya H, Suzuki K, Onuma T, Kikuchi M, Hoshi $H$ and Araki Y (1995) Molecular cloning and characterization of a mouse oviduct-specific glycoprotein Biology of Reproduction 53 285-294

Simmen RCM, Ko $Y$ and Simmen FA (1993) Insulin-like growth factors and blastocyst development Theriogenology 39 163-175

Smith GW, Goetz TL, Anthony RV and Smith MF (1994) Molecular cloning of an ovarian tissue inhibitor of metalloproteinases: ontogeny of messenger ribonucleic acid expression and in situ localization within preovulatory follicles and luteal tissue Endocrinology 134 344-352

Suarez, S, Redfem K, Raynor P, Martin F and Phillips DM (1991) Attachment of boar sperm to mucosal explants of oviduct in vitro: possible role in formation of a sperm reservoir Biology of Reproduction 44 998-1004

Sutton R, Nancarrow CD, Wallace ALC and Rigby NW (1984) ldentification of an cestrus-associated glycoprotein in oviductal fluid of the sheep Journal of Reproduction and Fertility 72 415-422

Suzuki K, Sendai $Y$, Onuma T, Hiroyoshi $H$, Hiroi $M$ and Araki $Y$ (1995) Molecular characterization of a hamster oviductspecific glycoprotein Biology of Reproduction 53 345-354

Swanchara KW, Henricks DM, Birrenkott GP, Bodine AB and Richardson ME (1995) Expression of epidermal growth factor (EGF) and the EGF receptor in the porcine oviduct Biology of Reproduction 53 911-922

Tuo W, Hamey JP and Bazer FW (1995) Colony-stimulating factor-1 in conceptus and uterine tissue in pigs Biology of Reproduction 53 133-142

Vaughan TJ, James PS, Pascall JC and Brown KD (1992) Expression of the genes for TGF $\alpha$, EGF and the EGF receptor during early pig development Development 116 663-669

Viuff D, Hyttel P, Greve T, Eriksen T and Alexandersen S (1995) Transcription and localization of growth factor mRNA in the bovine oviduct Molecular Reproduction and Development $4228-34$ 
Wallenhaupt K, Alm H, Tomek W and Brüssow K-P (1996) Studies on the influence of a specific $97 \mathrm{kd}$ porcine oviductal secretory protein on the de novo protein synthesis of preimplantation embryos Archives of Animal Breeding 3974

Watanabe T, Kobori K, Miyashita K, Fujii T, Saki H, Uchida M and Tanaka H (1993) Identification of glutamic acid 204 and aspartic acid 200 in chitinase A1 of Bacillus circulans WL-12 as essential residues for chitinase activity joumal of Biological Chemistry 268 18567-18572

Watson AJ, Hogan A, Hahnel A, Weimer KE and Schultz GA (1992) Expression of growth factor ligand and receptor genes in the preimplantation bovine embryo Molecular Reproduction and Development 31 87-95

Watson AJ, Watson PH, Arcellana-Panlilio M, Warnes D, Walker SK, Schultz GA, Armstrong DT and Seamark RF (1994) A growth factor phenotype map for ovine preimplantation development Biology of Reproduction 50 725-733

Werb $Z$ and Alexander CM (1993) Proteinases and matrix degradation. In Textbook of Rhiumatology pp 248-268 Eds WN Kelley, ED Harris, Jr, S Ruddy and CB Sledge. WB Saunders, Philadelphia
White KL, Hehnke K, Rickords LF, Southem LL, Thompson DL., Jr and Wood TC (1989) Early embryonic development in vitro by coculture with oviductal epithelial cells in pigs Biology of Reproduction 41 425-430

Winger QA, de los Rios P, Han VKM, Armstrong DT, Hill DJ and Watson AJ (1997) Bovine oviductal and embryonic insulinlike growth factor binding proteins: possible regulators of "embryotrophic" insulin-like growth factor circuits Biology of Reproduction 56 1415-1423

Wiseman DL, Henricks DM, Eberhardt DM and Bridges WC (1992) Identification and content of insulin-like growth factors in porcine oviductal fluid Biology of Reproduction 47 126-132

Woodcock S, Mormon J-P and Henrissat B (1992) Detection of secondary structural elements in proteins by hydrophobic cluster analysis Protein Engineering 5 629-635

Wu ASH, Carlson SD and First N (1976) Scanning electron microscopic study of the porcine oviduct and uterus journal of Animal Science 42 804-809 